\title{
HORMONAL INDUCTION OF ABORTION OF A MUMMIFIED FETUS IN A BREEDING WEIMARANER BITCH
}

\author{
Maša Efendić ${ }^{1}$ Marko Samardžija²*, Hrvoje Capak³, Goran Bačić², Nino Maćešić \\ ${ }^{1}$ Faculty of Veterinary Medicine, ${ }^{2}$ Clinic for Obstetrics and Reproduction, ${ }^{3}$ Department of Radiology, Ultrasound Diagnostic and Physical \\ Therapy, Faculty of Veterinary Medicine, University of Zagreb, Croatia \\ *Corresponding author, E-mail: smarko@vef.hr
}

\begin{abstract}
The case describes a four-year-old Weimaraner bitch with fetal death resulting in the resorption of two gestation sacks and mummification of a fetus on day 30 of gestation. An ultrasound diagnostic on the $22^{\text {nd }}$ day post-ovulation showed three normal gestation sacks. An ultrasound check-up 3 days later showed only one gestation sack with no heartbeat observed, while the diameter of the gestation sack did not correspond to the gestation period. The uterine wall was intact and the ovaries had corpus luteum bilaterally. The clinical status of the patient was physiological. On the $32^{\text {nd }}$ day post-ovulation, an ultrasound showed a big solid cyst on the left ovary. At the bifurcation of the uterus, there was a solid mass $(2.56 \mathrm{~cm} \times 3.18 \mathrm{~cm})$ with a lack of fetal fluid. The mass corresponded to mummified fetus. The progesterone level on day 34 of gestation was $31.94 \mathrm{ng} / \mathrm{mL}$. The bitch was negative for Canine herpes virus, Canine bocavirus and Brucella canis. The induction of the abortion started on day 34 post-ovulation with a combination of antiprogestine (Alizine ${ }^{\circledR}$ and synthetic prostaglandins, (Estrumate ${ }^{\circledR}$ ) given subcutaneously and intravaginally administered $\left(\right.$ Cytotec $\left.^{\circledR}\right)$. There were certain side effects during therapy, such as tachypnea, polydipsia, nesting and fever. During therapy, the uterine wall, embryo mass, ovaries and eventual occurrence of fluid in the lumen of the uterus were monitored daily. On the $57^{\text {th }}$ day post-ovulation, a mucosal dark discharge occurred. Ultrasound findings showed no presence of fetal mass persistence in the uterus. The bitch showed signs of heat three and half months after the abortion. In the next gestation, it was confirmed by ultrasound that a minimum of five vital fetuses were developing normally. It can be concluded that the described hormonal protocol is the option of choice for breeding bitches in order to avoid unnecessary and undesirable surgery.
\end{abstract}

Key words: fetal death; bitch; mummification; aglepristone; cloprostenol; misoprostol

\section{Introduction}

The case describes a four-year-old female Weimaraner dog which was artificially inseminated (AI) with fresh semen, followed by progesterone $\left(\mathrm{P}_{4}\right)$ level evaluation. It was its first insemination and conception. The semen donor was a fouryear-old Weimaraner with a good breeding history which had resulted in four litters. During both inseminations (on day one and day three of $\mathrm{P}_{4}$ level

Received: 5. January 2018

Accepted for publication: 24 April 2018 evaluation), the semen was of optimal quality, motility was over $90 \%$, and no signs of spermatozoa abnormalities were observed. Eight days after the first insemination, the herpes vaccine (Eurican Herpes $205^{\circledR}$, Merial, Lyon, France) was given s/c (a single dose containing $1 \mathrm{~mL}$ of $0.3-1.75 \mu \mathrm{g}$ of canine herpesvirus antigen).

\section{Case presentation}

The bitch was referred to the Clinic for Obstetrics and Reproduction at the Faculty of Veterinary Medicine in Zagreb, Croatia for 
monitoring of the gestation by ultrasound diagnostic. Ultrasonography (US) on the $22^{\text {nd }}$ day post-ovulation (post-OV) showed a minimum of three gestation sacks with a physiological volume of embryonic fluid (the diameter of the gestation sacks corresponded to the gestation period). The internal diameter and length of the gestation sack was measured in the direction of the uterine horn. The maximum length of the embryo size was measured when imaged in the longitudinal plane of the embryo.

Three days later $\left(25^{\text {th }}\right.$ day post-OV), a US check-up showed only one gestation sack but without any heartbeat, and the US measures of the diameter of the gestation sack were not related to the gestation period. The other two gestation sacks were not found. No signs of fluid were observed in the uterine lumen, while the endometrium appeared relatively homogenous and moderately hypoechoic. Both ovaries were of a normal size for metestrus and had several corpora lutea. The status of the patient was without any clinical change and without vaginal discharge.

The bitch was on an adequate diet and the owner claimed that the patient had not been exposed to any kind of stress during gestation. The hematological and biochemical blood parameters were within the reference ranges (IDEXX VetAutoread $^{\mathrm{TM}}$ Hematology Analyzer, USA; IDEXX, Catalyst Dx Chemistry Analyzer, USA). The $\mathrm{P}_{4}$ level was $29.06 \mathrm{ng} / \mathrm{mL}$ (VIDAS $12^{\circledR}$, Biomerieux, France).

On day 32 post-OV, US showed that the right ovary was of a normal size with corpus luteum, whereas the left ovary $(2.48 \mathrm{~cm} \times 2.32 \mathrm{~cm})$ had a big solid cyst $(3.0 \mathrm{~cm} \times 3.13 \mathrm{~cm})$ of irregular shape. In the uterine lumen, at the bifurcation, a solid hypoechoic encapsulated mass $(2.56 \mathrm{~cm} \times 3.18$ $\mathrm{cm})$ was observed with an absence of embryonic fluid. The intrauterine mass corresponded to the mummified fetus (reduced or without fluid and the absence of fetal heartbeat). The hypoechoic mass appeared as gray-white material without any organized fetal structures within the uterus. Radiography of the abdomen was unremarkable.

Due to the fact that the patient was a breeding bitch, an ovariohysterectomy was not a treatment option. Given that there is a lack of clinical data in literature on the hormonal induction of abortion of a mummified fetus in bitches, we started with the modified treatment protocol for abortion commonly used at the Clinic. The patient was hospitalized at the Clinic in order to observe possible side effects of the treatment and to monitor the uterine lumen by US (Philips, Affiniti $50 \mathrm{G}$, Philips ultrasound Inc., Bothell, WA, USA). The bitch was always examined in dorsal recumbency. The body of the uterus and both uterine horns were identified at each examination.

During medical management, it is important that the uterine wall stays intact, otherwise surgery (lavage of the uterine lumen) would be the only option. Before starting with the treatment protocol, we measured the $\mathrm{P}_{4}$ level and performed an intravaginal examination to check the cervix, which was closed without any vaginal excretion. The $\mathrm{P}_{4}$ level on day 34 of gestation was $31.94 \mathrm{ng} /$ $\mathrm{mL}$.

The bitch was negative for Canine herpesvirus (CHV), Canine bocavirus (CBoV), and Brucella canis based on vaginal smears and blood sample analyses of antibodies against $\mathrm{CHV}, \mathrm{CBoV}$ and $B$. canis.

The hormonal induction of the abortion started on day 34 post-OV following the application of antiprogestine (a progesterone blocker) and synthetic prostaglandins $\left(\mathrm{PGF}_{2 \text {-alpha }}\right)$ respectively, as shown in Table 1.

The antiprogestine aglepristone (Alizine ${ }^{\circledR}$, Virbac, Carros, France), in doses of $10 \mathrm{mg} / \mathrm{kg}$ $\mathrm{s} / \mathrm{c}$ once per day (QD), was administered over the following two days. US follow-up 24 hours after the second dose of aglepristone showed the same position and same diameter of the mummified fetus. Upon an intravaginal examination, a small amount of colorless mucus discharge was observed.

The day after the application of the second dose of aglepristone, a total dose of $1 \mathrm{mcg} / \mathrm{kg}$ (BID - 2 × $0.5 \mathrm{mcg} / \mathrm{kg}, \mathrm{s} / \mathrm{c}$ ) of $\mathrm{PGF}_{\text {2-alpha }}$ cloprostenol (Estrumate $^{\circledR}$, Intervet international BV, Zagreb, Croatia) was given. The first application of cloprostenol (day C.1) was applied on day 36 of gestation. Tachypnea occurred 10-15 minutes after cloprostenol application, and eight hours later a small amount of green mucus vaginal discharge was observed. By means of a US examination, it was observed that the fetal mass was $3.13 \mathrm{~cm} \mathrm{x}$ $2.6 \mathrm{~cm}$ in size. The left ovarian cyst was $3.3 \mathrm{~cm} \mathrm{x}$ $3.0 \mathrm{~cm}$ in size, while the left ovary was not visible. Using Color-Doppler US, remarkable perifollicular vascularity was observed. The hematological and biochemical parameters were within the referent ranges. 
Table 1: The hormonal treatment of the abortion using combination of antiprogestine and synthetic prostaglandins $\left(\mathrm{PGF}_{2-\text { alph }}\right)$ described by days with description of side effects.

\begin{tabular}{|c|c|c|c|c|c|}
\hline $\begin{array}{l}\text { Gestation } \\
\text { day }\end{array}$ & $\begin{array}{c}\text { Day of } \\
\text { cloprostenol }\end{array}$ & $\begin{array}{l}\text { Dosage of } \\
\text { aglepristone }\end{array}$ & $\begin{array}{c}\text { Dosage of } \\
\text { cloprostenol }\end{array}$ & $\begin{array}{l}\text { Dosage of } \\
\text { misoprostol }\end{array}$ & $\begin{array}{l}\text { Side effects } \\
\text { of hormonal treatment }\end{array}$ \\
\hline 34 & / & $10 \mathrm{mg} / \mathrm{kg}$ & / & / & / \\
\hline 35 & / & $10 \mathrm{mg} / \mathrm{kg}$ & / & / & / \\
\hline 36 & C. 1 & / & $1 \mathrm{mcg} / \mathrm{kg}$ & / & tachypnea \\
\hline 37 & C. 2 & / & $1.5 \mathrm{mcg} / \mathrm{kg}$ & / & tachypnea, minor depression \\
\hline 38 & C. 3 & / & $2 \mathrm{mcg} / \mathrm{kg}$ & / & tachypnea, depression \\
\hline 39 & C. 4 & / & $2.5 \mathrm{mcg} / \mathrm{kg}$ & / & tachypnea, depression \\
\hline $40-44$ & C.5- C.9 & / & $3 \mathrm{mcg} / \mathrm{kg}$ & / & tachypnea, nesting, vocalization \\
\hline 45 & C. 10 & / & $3 \mathrm{mcg} / \mathrm{kg}$ & $2 \times 200 \mathrm{mcg}$ & tachypnea, depression \\
\hline 46 & C. 11 & / & $3.5 \mathrm{mcg} / \mathrm{kg}$ & $2 \times 200 \mathrm{mcg}$ & $\begin{array}{c}\text { tachypnea, depression, fever, } \\
\text { vomiting }\end{array}$ \\
\hline 47 & C. 12 & / & $3.5 \mathrm{mcg} / \mathrm{kg}$ & $2 \times 200 \mathrm{mcg}$ & $\begin{array}{c}\text { tachypnea, depression, fever, } \\
\text { vaginal discharge, inappetence, } \\
\text { polydipsia }\end{array}$ \\
\hline $48-51$ & C.13- C.16 & / & $3.5 \mathrm{mcg} / \mathrm{kg}$ & $2 \times 200 \mathrm{mcg}$ & $\begin{array}{c}\text { tachypnea, depression, } \\
\text { vaginal discharge, inappetence, } \\
\text { polydipsia }\end{array}$ \\
\hline 52 & C. 17 & / & $3.5 \mathrm{mcg} / \mathrm{kg}$ & $1 \times 200 \mathrm{mcg}$ & $\begin{array}{c}\text { tachypnea, depression, vaginal } \\
\text { discharge, inappetence, } \\
\text { polydipsia, colic }\end{array}$ \\
\hline $53-56$ & C. $18-$ C. 21 & / & $3.5 \mathrm{mcg} / \mathrm{kg}$ & / & $\begin{array}{c}\text { tachypnea, depression, vaginal } \\
\text { discharge, inappetence, } \\
\text { polydipsia }\end{array}$ \\
\hline 57 & C. 22 & / & $3.5 \mathrm{mcg} / \mathrm{kg}$ & / & $\begin{array}{c}\text { tachypnea, depression, dark } \\
\text { brown } \\
\text { vaginal discharge, inappetence, } \\
\text { polydipsia }\end{array}$ \\
\hline
\end{tabular}



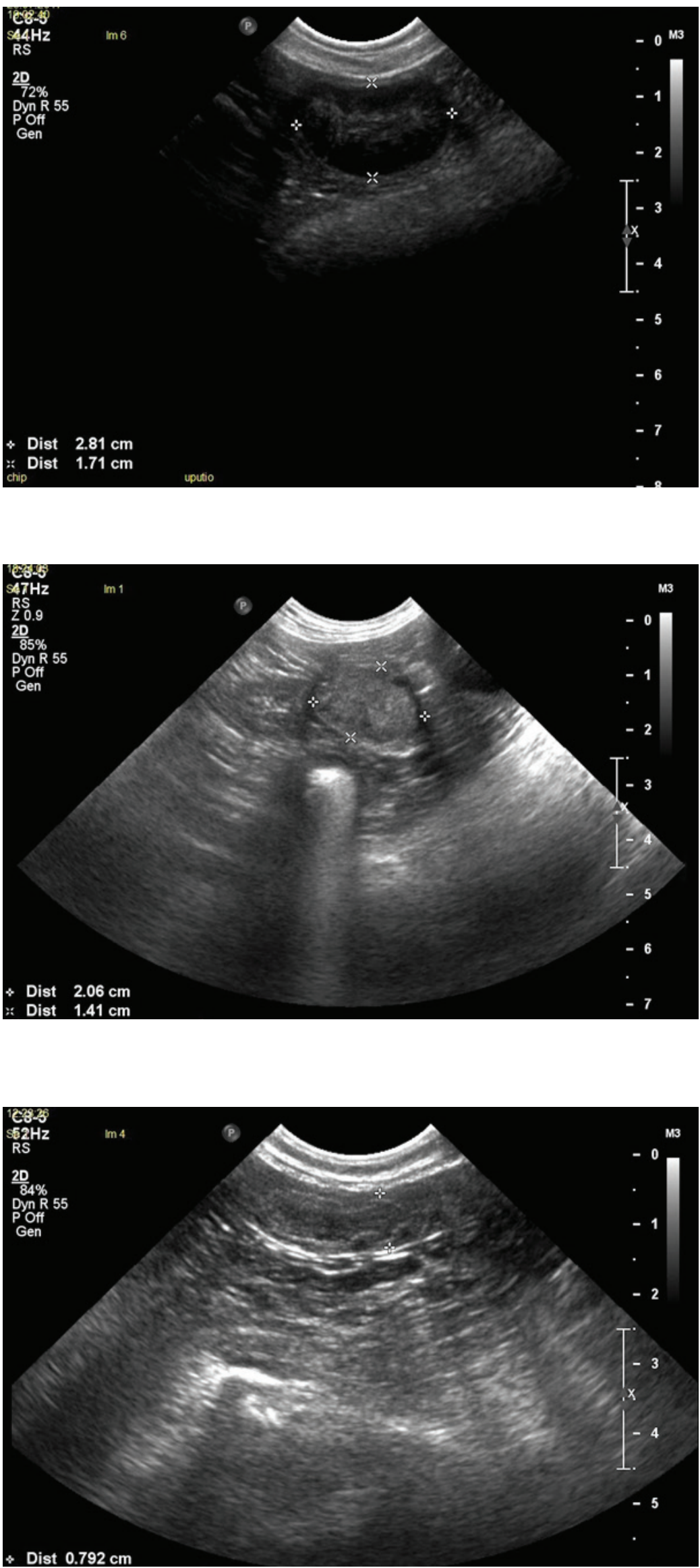

Figure 3: The ultrasound findings performed on day C.22 showed a normal uterus status without fetal formation. The diameter of the uterine corpus is $0.72 \mathrm{~cm}$ 
On day C.2, the total dose of cloprostenol was increased to $1.5 \mathrm{mcg} / \mathrm{kg}$ in two equal doses $(2 \mathrm{x}$ $0.75 \mathrm{mcg} / \mathrm{kg}$ ). A US examination showed an intact endometrium without uterine fluid. The fetal mass had decreased $(2.81 \mathrm{~cm} \times 1.71 \mathrm{~cm})$ and contained a small amount of fluid in the lumen (see Fig.1). The patient was clinically stable and showed minor depression. No vaginal discharge was observed.

On day C.3, the total dose of cloprostenol was increased to $2 \mathrm{mcg} / \mathrm{kg}$. Tachypnea occurred again following application. There was no vaginal discharge and the patient's clinical status was unchanged. During vaginal examination, the cervix was still closed.

The total cloprostenol dose on day C.4 was increased to $2.5 \mathrm{mcg} / \mathrm{kg}$. US examination of the fetal mass showed it had decreased $(2.4 \mathrm{~cm} \times 1.8$ $\mathrm{cm})$. A small amount of colorless vaginal mucus discharge occurred.

On the fifth day (day C.5), a total dose of 3 $\mathrm{mcg} / \mathrm{kg}$ of cloprostenol was given. Approximately 15 minutes after the first application, the bitch started nesting a few times for a short period. The bitch also started vocalization similar to that during estrus (near the ovulation period).

No vaginal discharge or elevation of body temperature was observed. In addition, the hematological and biochemical parameters were within the referent range.

On day C.6, the same total dose of cloprostenol ( $3 \mathrm{mcg} / \mathrm{kg}$ ) was given. By means of US, it was observed that the fetal mass had moved caudally towards the urinary bladder (US check-ups were regularly performed after urination). The shape of the mass became more oval and seemed subjectively larger $(2.8 \mathrm{~cm} \times 2.2 \mathrm{~cm})$, and the center area of the mass was observed as anechoic. The uterus was unchanged with no noticeable vaginal discharge. The same dose on days C.7, C. 8 and C. 9 was applied. US findings were the same as described earlier.

On day C.10, a total dose of $3 \mathrm{mcg} / \mathrm{kg} \mathrm{s} / \mathrm{c}$ of cloprostenol was applied, and a first dose of the synthetic prostaglandin $\mathrm{E}_{1}$ analog, misoprostol $\left(\right.$ Cytotec $^{\circledR}$, Pfizer limited, Kent, United Kingdom; 200 mcg tablets) was administrated intravaginally in order to induce an opening of the cervix. Recommended dose for intravaginal misoprostol for bitches weighing $<20 \mathrm{~kg}$ bw is $200 \mathrm{mcg}$ while for bitches weighing $>20 \mathrm{~kg}$ bw is 400 mcg per day as long as vaginal discharge does not occur (1). Since our patient weighed $34 \mathrm{~kg}$ bw, we applied misoprostol $2 \times 200$ mcg per day (BID). The tablet should be ground and melted in a small amount of sterile $0.9 \% \mathrm{NaCl}(0.154 \mathrm{~mol} / \mathrm{L})$ in a maximum volume of 2-3 $\mathrm{mL}$, and should be applied intravaginally by AI catheter. During misoprostol therapy, according to our Clinical protocol it is recommended to combine the treatment with systemic $\mathrm{PGF}_{2 \text { alpha }}$ (2). After a second dose of misoprostol, the patient was examined by US and the mass again seemed smaller. No side effects after misoprostol application occurred.

On day C.11, the total dose of cloprostenol was increased $(3.5 \mathrm{mcg} / \mathrm{kg})$ and application of misoprostol (2 x $200 \mathrm{mcg}$ intravaginally) was repeated. US examination revealed no change. The bitch became febrile $\left(39.4^{\circ} \mathrm{C}\right)$ and vomited twice but still had appetite.

Due to the fact that certain side effects had occurred, on day C.12 the dose of cloprostenol was not increased, and the treatment was the same as the day before. Four hours after the first dose of misoprostol on day C.12, a small amount of dark brownish mucus discharge appeared.

Since US showed no progression, misoprostol therapy was continued. The bitch still had the same body temperature $\left(39.4^{\circ} \mathrm{C}\right)$, and depression, inappetence and polydipsia (drinking 4-5 L per day) occurred. Polydipsia could be expected with a cloprostenol dosage above $3 \mathrm{mcg} / \mathrm{kg}$, and the therapy was continued due to the fact that the renal biochemical profile was within the reference range.

Polydipsia and depression continued on day C. $13(3.5 \mathrm{mcg} / \mathrm{kg}$ of cloprostenol and $2 \times 200$ mcg of misoprostol). The body temperature of the patient decreased to a normal range and no vaginal discharge was observed. Depression, inappetence and polydipsia were still present. Checking by means of US, it was noticeable that the mass formation had moved caudally, was positioned in front of the cervix, had decreased in diameter, and was not visible as encapsulated anymore but visible as a fluctuating form.

A small amount of light green mucus discharge occurred in front of the pseudocervix during a vaginal check-up on day C.14 (cloprostenol 3.5 $\mathrm{mcg} / \mathrm{kg}$ and misoprostol $2 \times 200 \mathrm{mcg})$. The bitch was clinically stable with the same side effects. On days C.15 and C.16, clinical and US findings, as well as the treatment and side effects, were the same as on day C.14.

On day C.17 (cloprostenol $3.5 \mathrm{mcg} / \mathrm{kg}$ ), the misoprostol dosage was reduced to QD $(1 \times 200$ 
mcg) due to the fact that on the previous two days the bitch had a small amount of brown vaginal discharge and started presenting coliclike symptoms following misoprostol application. The patient still had tachypnea, depression, inappetence and polydipsia. A US check-up showed endometrial hyperplasia with a small amount of intrauterine fluid proximal to the mass formation $(2.06 \mathrm{~cm} \times 1.41 \mathrm{~cm})$ in the corpus (we assumed that it was $\mathrm{NaCl}$ saline used for melting misoprostol), as shown in Figure 2. If the aforementioned assumption was correct (presence of intrauterine fluid), it could be concluded that the cervix had opened. Due to the fact that the mass formation had decreased, our hypothesis is that the $\mathrm{NaCl}$ saline had passed around the mass formation and filled the uterine corpus.

After the appearance of the fluid in the uterus, on day C. 18 cloprostenol $(3.5 \mathrm{mcg} / \mathrm{kg} \mathrm{s} / \mathrm{c}$ in total) without misoprostol was administrated. Seven hours later, during a US examination there was no fluid in the uterus and the endometrial wall seemed intact. We assumed that the mentioned change in the endometrial findings could be ascribed to the beneficial $\mathrm{PGF}_{2 \text { alfa }}$ therapy.

A small amount of light brown mucus vaginal discharge appeared from day C.19 until day C.21. On the mentioned days, cloprostenol therapy $(2 \times 1.75$ $\mathrm{mcg} / \mathrm{kg} \mathrm{s} / \mathrm{c}$ ) without misoprostol administration was continued. US examination revealed the fetal form decreased on a daily basis towards day C.22.

On day C.22, the $57^{\text {th }}$ day post-OV, a huge amount of dark brown vaginal discharge appeared two hours following the first dose of cloprostenol $(1.75 \mathrm{mcg} / \mathrm{kg} \mathrm{s} / \mathrm{c})$.

The US findings showed a normal uterine status without fetal formation (see Fig. 3), which was checked and confirmed by US next day.

The recommendation to the owner was to inseminate the bitch in the next estrus cycle. There was an assumption that the next cycle might be earlier than expected due to the hormonal treatment shortening the luteal phase of the cycle. The bitch showed signs of heat three and a half months (103 days) after the abortion. In the next gestation, on day 35 post-OV, it was confirmed by US that a minimum of five vital fetuses were developing normally, while on the day 55 following conception X-ray findings determined 10 fetal skeletons. On the day 60 post-OV bitch has delivered 10 vital puppies by physiological parturition.

\section{Discussion}

Pregnancy is a normal physiological state which can be interrupted by disorders in gestation. Abnormalities in pregnancy are not an uncommon presentation in clinical veterinary practice and may manifest as pregnancy loss or a variety of metabolic conditions that occur during pregnancy (3). Pregnancy loss may occur at any stage of gestation in a bitch (4), and may manifest as embryonic death and resorption, abortion of a live or dead fetus, stillborn pups, or embryo/fetal mummification and retention in the dam's uterus or peritoneal cavity beyond the normal time of parturition (5).

Early fetal death is characterized ultrasonographically by the presentation of fetal anatomy without a heartbeat (3). If fetal death occurs during the first half of pregnancy, resorption or unobserved abortion occurs (6). In our case, the bitch had two types of pregnancy loss. The first type was two embryonic deaths between days 2325 of gestation, resulting in embryonic resorption, while the second type was an embryonic death with mummification which occurred in the period between days 25 and 32 of gestation.

The resorption of gestation sacks in our case followed the same changes as described in other study (7), such as delayed development of the embryo, delayed detection of embryonic heartbeat, a small embryonic length, and measurement of a slow growth rate by US. However, no studies have reported in detail the features of embryos which subsequently resorbed (7). Some authors (8) mentioned that there are many potential causes of resorption, such as embryonic abnormalities, abnormal maternal environment and infectious agents. There are scientific findings (4) which explain that luteal insufficiency has been hypothesized as a cause of spontaneous abortion in bitches. However, in our case it was not the cause of the pregnancy loss, due to the high $\mathrm{P}_{4}$ level (31.94 ng/mL).

Some authors (9) have described the causes of resorption of fetal fluid leading to embryo/fetal mummification. The uterus contracts against the fetus, which causes the absorption of fetal fluid and the fetal membranes become shriveled and dried, which happened in our case with the third gestation sack. Based on our US findings of the mummified mass formation, it can be concluded 
that embryonic death occurred on day 30 of gestation. Due to the fact that mummification develops in sterile conditions, the future fertility of animals is not affected (10). Scientific study (11) states that fetal mummification is mostly caused by the Canine herpes virus (CHV). However, in our case the bitch was negative for CHV.

The type of treatment outcome depends on the following causes: embryonic/fetal death, the stage of pregnancy, and fetal/maternal immunocompetence (4).

The current case is interesting because fetal mummification in female dogs is rare (8), and in most cases the treatment of choice is ovariohysterectomy. One case report (9) describes an unsuccessful attempt to hormonally induce abortion in a bitch with a single dose of estrogen and oxytocin. Since there was no response to such therapy, a cesarean section was performed to remove the mummified fetus while the other report described treatment of the mummification only by cesarean section (10).

Due to the fact that our patient was a breeding bitch and it was her first conception and gestation, we decided to start with a modified hormonally induced abortion of the mummified embryo. However, we were aware that, due to mummification, the uterus response to $\mathrm{PGF}_{2}$ alpha treatment would be reduced and medical management challenging.

\section{Conclusion}

Given the lack of scientific data regarding hormonal induction of abortion of embryo/ fetal mummifications, the current case study has resulted in significant information about a hormonal protocol with a beneficial outcome. In addition, we managed to monitor the bitch by US on a daily basis, which gave us useful information regarding the uterine response to hormonal therapy, appropriate dosages of the hormones applied, the kinetics of decreasing embryo size and formation, and possible side effects of medical management using a combination of aglepristone, cloprostenol and misoprostol.

Finally, it can be concluded that the described hormonal protocol in the current study is the option of choice for breeding bitches in order to avoid unnecessary and undesirable surgery.

\section{References}

1. Agaoglu AR, Schäfer-Somi S, Kaya D, et al. The intravaginal application of misoprostol improves induction of abortion with aglepristone. Theriogenology 2011; 76: 74-82.

2. Špoljarić B, Svoboda D, Vince S, et al. Pharmacological methods for induction of abortion in bitches. Vet Stn 2018; 49: 441-53.

3. Davidson A. Clinical approach to abnormal pregnancy. In: England G, von Heimendahl A, eds. BSAVA manual of small animal reproduction and neonatology. Quedgeley, Gloucester : British Small Animal Veterinary Association, 2010: 115-20.

4. Romagnoli S. Complications in canine pregnancy and their clinical approach. In: Proceedings of the Veterinary Sciences Congress. Oeiras, Portugal, 2002: 159-62.

5. Singla VK, Varughese EE, Upasana R, Bhat GR, Gandotra VK. Resorption of multiple fetuses at mid-gestation in a bitch. Indian $\mathrm{J}$ Anim Reprod 2012; 33: 104-6.

6. Johnston DS, Root Kustritz MV, Olson PNS. Canine and feline theriogenology. Philadelphia : Saunders, 2001: 87.

7. England GCW, Russo M. Ultrasonographic charecteristics of early pregnancy failure in bitches. Theriogenology 2006; 66: 1694-8.

8. England GCW. Pregnancy diagnosis, abnormalities of pregnancy and pregnancy termination. In: Simpson G, England G, Harvey M, eds. BSAVA manual of small animal reproduction and neonatology. Quedgeley, Gloucester: British Small Animal Veterinary Association, 2004: 113-25.

9. Mudasir O, Shah KA, Nyrah O, Andrabi A. Fetal mumification in a bitch. VetScan 2012; 7(1): art. 115. http://www.vetscan.co.in/v7n1/Fetal-Mummification-in-a-Bitch.pdf (29. 12. 2017)

10. Vikram R, Chaudhary GR, Sivanarayanana TB, Sushobhit S, Narayanan K. Successful treatment of fetal mummification in a bitch by caesarean section: a case report. Theriogenology Insight 2015; 5(2): 147-51.

11. Long S. Abnormal development of conceptus and its consequences. In: Noakes DE, Parkinson TJ, England GCW, eds. Veterinary reproduction and obstetrics. London : Saunders, 2009: 123-5. 


\title{
HORMONALNA SPODBUDITEV SPLAVA MUMIFICIRANEGA PLODU PRI PLEMENSKI PSICI PASME WEIMARANEC
}

\author{
M. Efendić, M. Samardžija, H. Capak, G. Bačić, N. Maćešić
}

Povzetek: Opisan je primer štiriletne plemenske psice pasme weimaranec, pri kateri je prišlo do smrti več plodov, kar je povzročilo resorpcijo dveh gestacijskih vreč in mumifikacijo ploda 30. dan brejosti. Ultrazvočna diagnostika 22 dni po ovulaciji je pokazala tri običajne gestacijske vrečke. Pregled z ultrazvokom 3 dni kasneje je pokazal samo eno gestacijsko vrečko brez opaznega srčnega utripa, premer gestacijske vrečke pa ni ustrezal času trajanja brejosti. Maternična stena je bila videti nepoškodovana, na obeh jajčnikih pa so bila opazna rumena telesca. Klinični status psice je kazal fiziološke znake brejosti. 32 . dan po ovulaciji je ultrazvok pokazal veliko trdno cisto levega jajčnika. Na razcepu maternice je bila trdna masa $(2,56 \mathrm{~cm} \times 3,18 \mathrm{~cm}) \mathrm{s}$ pomanjkanjem fetalne tekočine. Masa je ustrezala mumificiranemu plodu. Raven progesterona v krvi 34. dan brejosti je bila 31,94 ng/ml. Psica je bila negativna na pasji herpesvirus, pasji bokavirus in na Brucello canis. S spodbuditvijo splava smo pričeli 34 dni po ovulaciji s kombinacijo antiprogestina (Alizine ${ }^{\circledR}$ ) in sintetičnih prostaglandinov (Estrumate ${ }^{\circledR}$ ), ki smo jih dajali podkožno in intravaginalno $\left(\right.$ Cytotec $\left.^{\circledR}\right)$. Med zdravljenjem so se pokazali nekateri neželeni učinki, kot so tahipneja, polidipsija, gnezdenje in povišana telesna temperatura. Med zdravljenjem smo dnevno spremljali debelino maternične stene, maso plodu, jajčnike in morebitno pojavljanje tekočine v lumnu maternice. 57. dan po ovulaciji se je pojavil sluzast temen izcedek. Ultrazvočni pregled ni pokazal prisotnosti mase plodu v maternici. Psica je kazala znake gonitve tri mesece in pol po splavu. V naslednji brejosti je bilo z ultrazvokom potrjeno, da se normalno razvija najmanj pet vitalnih plodov. Glede na rezultate lahko predlagamo opisano hormonsko zdravljenje kot možno izbiro za spodbujen splav pri plemenskih psicah, da bi se izognili nepotrebnim in neželenim operacijam.

Ključne besede:smrt plodov; psica; mumifikacija; aglepriston; kloprostenol; misoprostol 